\title{
Sea urchin pathogen: a possible tool for biological control
}

\author{
Robert J. Miller \\ Halifax Fisheries Research Laboratory, Department of Fisheries and Oceans, P. O. Box 550, Halifax, N. S. B3J 2S7, Canada
}

\begin{abstract}
A sea urchin pathogen recently exerted great impact on the Nova Scotia near-shore community by releasing large areas of habitat to seaweed colonization and growth. The pathogen has promise for use as a tool for biological control because it is virulent, apparently species specific, can be maintained and transferred in the laboratory, and is waterborne. The purpose of this study was to demonstrate that it could be transferred from the laboratory to the field. This was accomplished in a reciprocal transplant experiment. Sea urchins from 2 sites $3.5 \mathrm{~km}$ apart were brought to the laboratory; one group was exposed to the disease-causing agent and the other served as control. Both groups were returned to the field but released at opposite sites. Sea urchins naturally occurring near the release of the exposed sea urchins developed disease symptoms within $4 \mathrm{wk}_{i}$ and by $8 \mathrm{wk}$ when the temperature became too low for transfer of disease, diseased sea urchins were found as far as $120 \mathrm{~m}$ from the release site. No disease occurred at the control site by $8 \mathrm{wk}$ or in 5 additional areas within a few kilometers of the 2 release sites
\end{abstract}

\section{INTRODUCTION}

Sea urchin domination of shallow, rocky marine habitat to the exclusion of macroalgae (except calcareous forms) is very well documented. In St. Margarets Bay, a well-studied embayment in Nova Scotia, about $10 \%$ of this habitat was dominated by the green sea urchin Strongylocentrotus droebachiensis and $90 \%$ by macroalgae in 1968 (Mann, 1972). Sea urchin domination increased to $60 \%$ by 1973 (Breen and Mann, 1976) and to $90 \%$ by 1978 (Chapman, 1981). In areas where sea urchins were removed experimentally macroalgae re-established $100 \%$ cover within a few months (Breen and Mann, 1976; Chapman, 1981). Lawrence (1975) reviewed 38 cases of sea urchin-dominated barren grounds worldwide. In several of these, as in St. Margarets Bay, macroalgae colonized the bottom after sea urchins were removed experimentally.

Macroalgae are obviously beneficial to the marine plant industry (e. g. giant kelp in California and Irish moss in Nova Scotia). By contributing primary production and habitat complexity they may also enhance finfish abundance (e. g. Quast, 1968); Simenstad et al., 1977; Leaman, 1980; Moreno and Jara, 1984) and shellfish yields (Wharton and Mann, 1981). The degree of enhancement remains a subject of discussion
(Quast, 1968; Pringle et al., 1982) and ongoing research.

Artificial methods of controlling sea urchins have included the employment of SCUBA divers to break sea urchins with hammers or to spread calcium oxide over aggregations of sea urchins (North, 1974). Because these methods are expensive and must often be repeated to produce lasting effects, they are practical on only a small scale.

Documented cases of sea urchin mortality due to disease suggest this as a tool for biological control. Three localized cases of Strongylocentrotus franciscanus mortalities in California were of a few month's duration and a few hectares in area (Johnson, 1971; Pearse et al., 1977). In one area the canopy of Macrocystis pyrifera expanded by over 10 ha following the mortalities (Pearse and Hines, 1979). Three sea urchin species (Paracentrotus lividus, Sphaerechinus granularis, Arbacia lixula) were affected by localized mass mortalities along the European coast of the Mediterranean during 1978-1979 (L. Fenaux, Station Zoologique at Villefranche-sur-Mer, pers. comm.). Explosive growth of epiphytes on seagrass followed mortality of $P$. lividus on the Mediterranean coast of France (Boudouresque et al., 1981). Widespread mortality of Diadema antillarum has occurred recently 
throughout the Caribbean (Lessios et al., 1983; Bak et al., 1984). On the south coast of Nova Scotia at least $250,000 \mathrm{t}$ of $S$. droebachiensis died of disease from 1980 through 1983 . This near complete mortality along $1,400 \mathrm{~km}$ of shoreline released at least $500 \mathrm{~km}^{2}$ of habitat to colonization by macrophytes. If this colonization leads to mature beds, algal biomass will increase by about 1.8 million $t$, and annual net production by about 7 million $t$ (Miller, 1984). In none of these cases has the disease agent been positively identified.

The disease agent(s) causing mass mortalities in Nova Scotia has several characteristics which make it favourable for use in biological control. It is transferable in the laboratory; it can be maintained in the laboratory for at least one year; it is waterborne; it appears to be species specific; and sea urchins lack natural resistance to it at warm temperatures (at least in the laboratory) (Miller and Colodey, 1983; Miller, 1984, Scheibling and Stephenson, 1984). To be useful in biological control the agent must also be transferable from the laboratory to a field population of sea urchins. The purpose of this study was to demonstrate such a transfer

Experimental and control sites, labelled D (diseased) and $H$ (healthy) respectively are located $3.5 \mathrm{~km}$ apart in eastern Nova Scotia (Fig. 1). Both sites are exposed

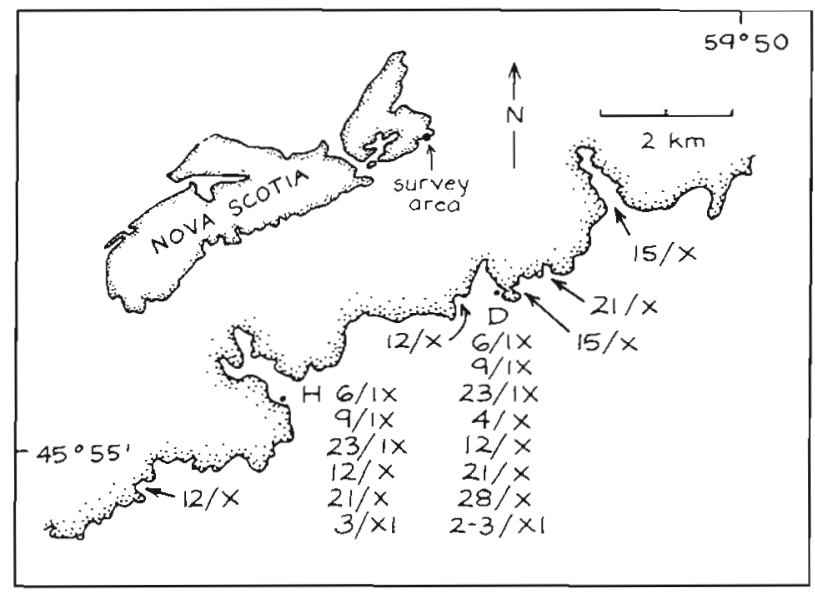

Fig. 1. Site of release of diseased (D) and healthy sea urchins $(\mathrm{H})$; other sites inspected for presence of diseased sea urchins; dates each site was visited

to the open Atlantic over about a $30^{\circ}$ arc; the substratum at both sites is a mixture of boulders and granite bedrock; and water depths are $6 \mathrm{~m}$ below chart datum at Site $\mathrm{D}$ and $3.5 \mathrm{~m}$ at Site $\mathrm{H}$.

The choice of study sites had the following constraints. (1) Sea urchin density should be high to aid in transfer of the waterborne disease agent among individuals. The minimum required density is not known. (2) Water temperature should be high enough to allow transfer of the disease within a few weeks. In laboratory exposures Scheibling (1984) reported time to $50 \%$ morbidity as less than $10 \mathrm{~d}$ for 15 to $22^{\circ} \mathrm{C}$ but about 30 d at $12{ }^{\circ} \mathrm{C}$, the minimum temperature at which disease could be transferred. In laboratory exposures at $17^{\circ} \mathrm{C}$ urchins from 4 locations were $100 \%$ moribund by $14 \mathrm{~d}$ (Miller, 1984). (3) Natural occurrence of the disease should be avoided; but (4) until more is known of its pathogenicity it should not be introduced far from its known area of distribution. The easternmost point where mass motalities were previously identified was Louisbourg in 1981 (Miller and Colodey, 1983), about $10 \mathrm{~km}$ west of Site D. At several dive sites east of Louisbourg (Fig. 1) sea urchins were large and abundant; and subtidal macroalgae were absent in 1983, suggesting that any recent sea urchin mortalities were slight. (5) Logistic considerations required that the study sites be near a safe harbour and have at least partial shelter from ocean swells so that diving was not so restricted by weather. These constraints limited the choice of experimental sites to within tens of kilometers of those chosen.

\section{METHODS}

A reciprocal transplant experiment begun on August 26, 1983 is summarized in Table 1. Apparently healthy sea urchins within the size range 3 to $6 \mathrm{~cm}$ diameter were collected from Sites D and $\mathrm{H}$ (Fig. 1) by SCUBA divers. Bottom temperature was $18^{\circ} \mathrm{C}$. On the same day these urchins were brought to Halifax and placed in tanks with running sea water maintained at $16{ }^{\circ} \mathrm{C} \pm 1 \mathrm{C}^{\circ}$. Beginning on August 29 sea urchins from Site $\mathrm{H}$ were exposed to diseased sea urchins taken

Table 1. Study schedule, Autumn 1983

\begin{tabular}{|c|c|}
\hline Date & Activity \\
\hline Aug 26 & $\begin{array}{l}\text { Sea urchins collected from Sites } \mathrm{D} \text { and } \\
\mathrm{H} \text { and placed in laboratory tanks }\end{array}$ \\
\hline Aug 29-Sep 6 & $\begin{array}{l}\text { Sea urchins from Site } \mathrm{H} \text { exposed to dis- } \\
\text { eased sea urchins from laboratory stock }\end{array}$ \\
\hline Sep 6 & $\begin{array}{l}\text { Disease-exposed sea urchins from Site } H \\
\text { released at Site D, and non-exposed sea } \\
\text { urchins from Site D released at Site H }\end{array}$ \\
\hline Sep 9-Oct 21 & $\begin{array}{l}\text { Qualitative observations on presence of } \\
\text { disease at Sites } D \text { and } H\end{array}$ \\
\hline Oct 12-21 & $\begin{array}{l}\text { Qualitative observations on presence of } \\
\text { disease at five additional sites }\end{array}$ \\
\hline Oct $28-$ Nov 3 & $\begin{array}{l}\text { Sites } D \text { and } H \text { sampled quantitatively } \\
\text { for numbers of sea urchins healthy and } \\
\text { moribund or dead }\end{array}$ \\
\hline
\end{tabular}


from a laboratory stock maintained since the previous autumn. This diseased stock had been maintained by continually adding healthy animals to, and removing dead animals from, a tank of running sea water kept at $>14^{\circ} \mathrm{C}$. To expose the sea urchins from Site $\mathrm{H}_{\text {, stock }}$ sea urchins with obvious external symptoms of disease were placed in the tank in mesh bags. This exposure was continued, replenishing diseased sea urchins as they died, until September 6.

On September 6 both exposed and unexposed lots were counted, weighed, boxed, and taken to the release sites. Before the releases the center of each site was marked with a subsurface buoy and most of the resident sea urchins were removed from a $3 \mathrm{~m}$ diameter circle. At Site D, 580 sea urchins totalling $22 \mathrm{~kg}$ which had been collected from Site $\mathrm{H}$ and exposed to disease were released in a 2 to $3 \mathrm{~m}$ diameter circle. At Site $\mathrm{H}, 330$ sea urchins totalling $10 \mathrm{~kg}$ that had been collected from Site D and not exposed to disease were also released in a 2 to $3 \mathrm{~m}$ diameter circle. If the disease subsequently appeared at Site $\mathrm{H}$ it would be either because it occurred there naturally or because it was introduced with the unexposed urchins from Site D.

During the next 7 wk, Sites $H$ and $D$ were visited 4 and 5 times respectively to record the presence or absence of diseased urchins. During these visits the release sites were examined carefully with a more cursory look up to $40 \mathrm{~m}$ distance

After the disease was noted to be spreading from Site D, 5 neighboring areas were also visited. In each area divers swam a few hundred meters within depths of 1 and $10 \mathrm{~m}$. Sea urchins were very abundant and the substratum was bedrock and boulders in all areas.

After the water temperature had fallen to $10^{\circ} \mathrm{C}$, below the temperature at which the disease was expected to spread (Scheibling, 1984), sea urchins near Sites $\mathrm{D}$ and $\mathrm{H}$ were sampled quantitatively. Four radial transects were laid out at approximately right angles. Samples were taken at 5 and $20 \mathrm{~m}$ from Site $\mathrm{H}$, and at $5,10,20$, and succeeding $20 \mathrm{~m}$ intervals from Site D. The numbers of sea urchins $\geqslant 2 \mathrm{~cm}$ diameter were counted in each of 4 quadrats, 0.5 by $1.5 \mathrm{~m}$, giving a total sample area of $3 \mathrm{~m}^{2}$ at each location. The counts were partitioned into 2 categories: live without disease symptoms, and moribund or dead. Dead sea urchins were counted only if more than one-half the test was intact. The mean percentage moribund or dead was compared statistically among locations on a transect using one-way analysis of variance. The percentage data were first transformed to logits (Y),

$$
Y=\log _{e}[(g+1 / 2) /(n-g+1 / 2)]
$$

where $\mathrm{n}=$ total number of sea urchins in a quadrat; $\mathrm{g}=$ number moribund or dead. This transformation tends to normalize distributions of proportions even when they span a large range of values and is superior to the more common arc-sine transformation when $n$ includes some small values (Snedecor and Cochran, 1967)

Temperatures were taken with a stem thermometer; they ranged from 14 to $16^{\circ} \mathrm{C}$ until early October, then gradually declined to $9^{\circ} \mathrm{C}$ by early November.

The occurrence of sea urchin disease was determined by the presence of external symptoms. Failure to hold on to the substratum is the most obvious. This is accompanied by gaping lantern teeth, retracted tube feet, and later by drooping and missing spines (Miller and Colodey, 1983). A few bare, intact tests and broken tests with or without spines are common in most field aggregations; however, a larger number of bare tests or even a few whole unattached urchins with spines are evidence of the disease. The distinction between moribund and dead sea urchins is not easy to determine in the field and will not be made in this paper.

A test was conducted in Halifax Harbour during October, November, and December 1983 to measure the time required for dead sea urchins to lose their spines and for their tests to break apart. Fifty apparently healthy sea urchins of 4 to $6 \mathrm{~cm}$ diameter were killed by immersing them in sea water at $50{ }^{\circ} \mathrm{C}$ for $30 \mathrm{~s}$. They were immediately placed in a net-enclosed cage to protect them from large scavengers and suspended from a wharf in a sheltered location. They were observed frequently over the next $55 \mathrm{~d}$ at temperatures of 12 to $4{ }^{\circ} \mathrm{C}$.

\section{RESULTS}

In the cage experiment in Halifax Harbour spine loss from dead sea urchins was abrupt: from slight at $6 \mathrm{~d}$, to greater than $50 \%$ at $8 \mathrm{~d}$, to near total at $9 \mathrm{~d}$. Tests broke apart at a more gradual rate: from $10 \%$ at $19 \mathrm{~d}$, to $50 \%$ at $30 \mathrm{~d}$, to $90 \%$ at $48 \mathrm{~d}$. Thus, the presence of spines on tests indicates recent mortality while denuded and broken tests indicate older mortalities.

On September 9, 3 d after the sea urchins were released, newly broken tests with spines still attached were common at both Sites $\mathrm{D}$ and $\mathrm{H}$. The type of damage was indicative of rock crab Cancer irroratus and lobster Homarus americanus predation (Himmelman and Steele, 1971). Both predators were common at both sites. The sea urchins were weak and probably unable to attach firmly to the substratum after being out of water for about $9 \mathrm{~h}$ during transport from Halifax. Thus, they would have been vulnerable to predation. A few unattached (moribund or dead) sea urchins remained intact at Site $D$; however, most individuals at both sites were firmly attached. 
On September 23 no unattached sea urchins were present at Site $\mathrm{H}$; but at least 50 were unattached and intact at Site D, most with spines. These were assumed to be released sea urchins which succumbed to disease.

By October 4 the disease appeared to be spreading at Site D. Sea urchins with disease symptoms were found up to $10 \mathrm{~m}$ from the release site.

A more extensive search on October 12 revealed no evidence of disease at or near Site $H$ but widespread occurrence near Site D. At least $50 \%$ were moribund or dead within a $5 \mathrm{~m}$ radius of the release site. The proportion decreased to zero at about $40 \mathrm{~m}$ in each of 2 directions. Most unattached urchins still had spines.

On October 21 the extent of dead and moribund sea urchins at Site D was similar to that on October 12 ; but a larger fraction, approximately $40 \%$, had lost their spines. Dr. J. H. Himmelman (Laval University), participated in this site visit and recorded a decrease in the fraction of diseased animals at increasing distance from the release site. Diseased urchins were found to a maximum distance of $50 \mathrm{~m}$. There was again no evidence of disease at Site $\mathrm{H}$.
During October 12 to 21,3 to $17 \mathrm{~d}$ after the disease was first noticed to be spreading from Site D, 5 neighboring areas, indicated in Fig 1, were examined. The closest of these were $0.6 \mathrm{~km}$ to the east and $0.6 \mathrm{~km}$ to the west of Site $D$. No evidence of disease was observed at any of these 5 areas.

A severe storm passed over the study area on October 24 and 25, delaying the quantitative sampling. Sampling was commenced on October 28, but the presence of large ocean swells further delayed its completion until November 2 and 3. The storm almost certainly carried away and broke into pieces many of the dead and moribund sea urchins; however, the impact of disease was still quite apparent.

Near Site D moribund and dead sea urchins comprised a large proportion of the population, but this proportion decreased sharply with increasing distance (Fig. 2). On the northward transect the decrease was from 57 to $6 \%(\mathrm{P}<0.01)$ over the first $40 \mathrm{~m}$. Beyond $40 \mathrm{~m}$ there was no evidence of disease, including stations $20 \mathrm{~m}$ east and west of the transect. On a $20 \mathrm{~m}$ transect ending in a small cove eastward of the release site the percentage moribund and dead also decreased

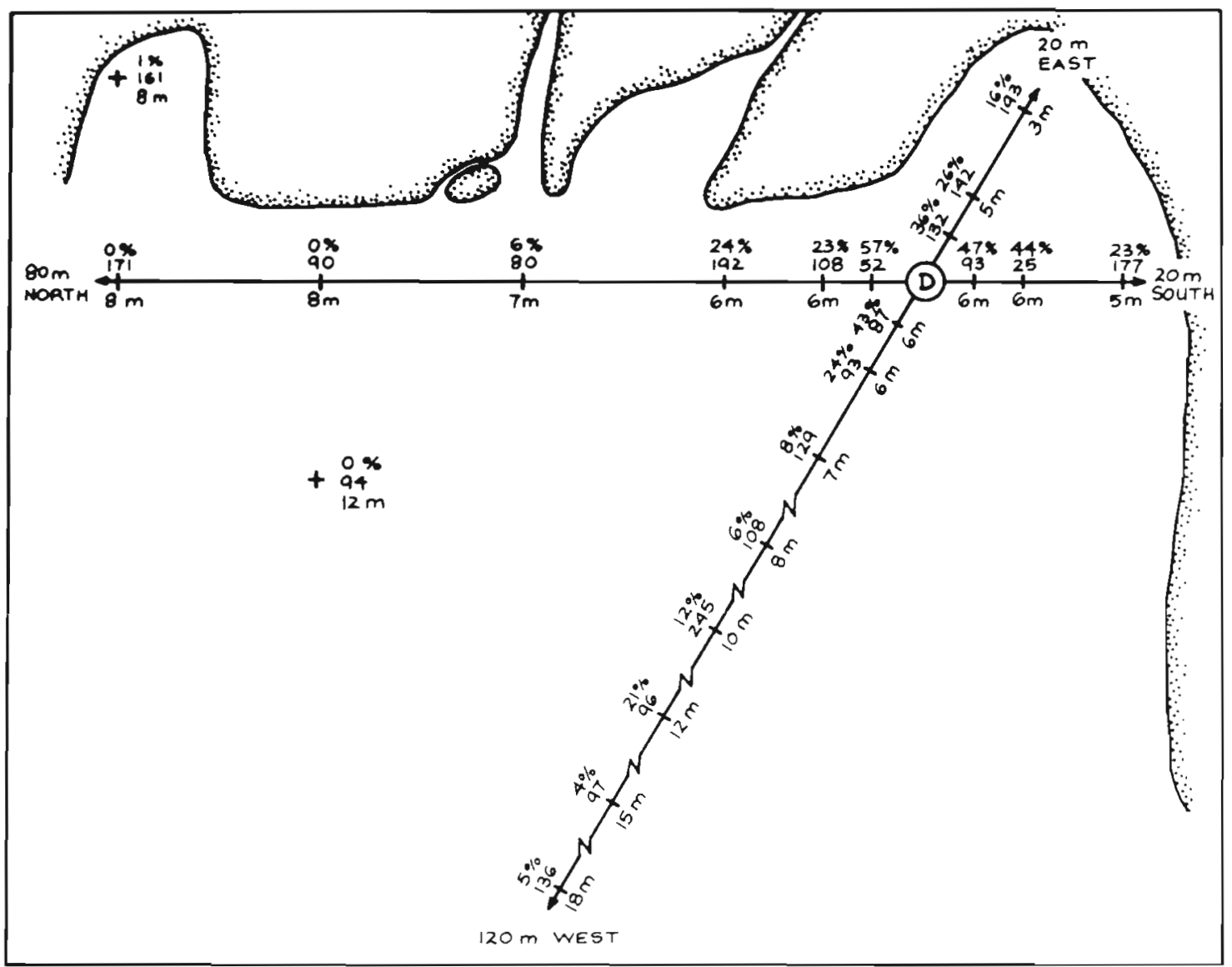

Fig. 2. Results of quadrat sampling near the release site of diseased sea urchins (D). Top number: mean percentage moribund or dead; middle number: total number of sea urchins counted; bottom number: water depth (m) 
significantly $(P<0.05)$. The decrease in percentage moribund and dead was not statistically significant $(P>0.05)$ along a $20 \mathrm{~m}$ transect which ran southward, ending near the base of a wall forming the side of the cove. The westward transect ran away from shore and ended where the bottom changed from bedrock to sand. There, moribund and dead individuals decreased from 43 to $6 \%$ ( $P<0.01$ ) over the first $40 \mathrm{~m}$, increased to $21 \%$ at $80 \mathrm{~m}$, then decreased again to $6 \%$ at $120 \mathrm{~m}(\mathrm{P}<0.05)$. The increase at $80 \mathrm{~m}$ may reflect the pattern of transfer of the disease or may represent an accumulation of the unattached animals resulting from the wave patterns of the late-October storm.

Near Site H quantitative sampling provided no evidence of disease. For the 4 sampling locations $5 \mathrm{~m}$ from the release site, 3 of 409 sea urchins were dead; at the 4 locations $20 \mathrm{~m}$ from the release site, 9 of 295 sea urchins were dead. The absence of disease at Site $\mathrm{H}$ indicates that it had not occurred naturally there and that it had not occurred naturally at Site D, the source of the sea urchins planted at Site $H$.

\section{DISCUSSION}

Considering that the disease is waterborne, the pattern of dispersion from an epicenter was remarkably clear. Sea urchins with disease symptoms were confined to less than $60 \mathrm{~m}$ to the north and were rare $120 \mathrm{~m}$ to the west. They were not found $600 \mathrm{~m}$ or further to the east and west.

According to Debach (1974) a natural enemy (pathogen, parasite, or predator) well suited for biological control: (1) is a good searcher for its host, (2) has higher reproductive capacity than its host, (3) responds rapidly to an increase in host density, (4) has high host specificity, and (5) tolerates as broad a range of environmental conditions as its host. Given the rapid spread of mass mortalities from 1980 through 1983 the sea urching pathogen can be considered a good searcher and to have a high reproductive capacity. Response to host increase is not well documented in the field, although in 1983 it was responsible for a kill of sea urchins that appeared following the 1980 and 1981 mortalities (Miller, 1984). No unusual mortalities of other species have been observed during field surveys over the 4 yr when urchin mass mortalities have occurred. Thus, it appears to be host specific, at least among benthic macrofauna. Casual observations in the laboratory on several benthic species /Cancer irroratus, Carcinus maenas, Homarus americanus, Mytilus edulis, Modiolus modiolus, Crassostrea virginica, Littorina littorea, Asterias sp., Echinarechinus parma) placed in tanks with diseased sea urchins in 1981-82 support this conclusion. The pathogen may not tolerate as broad a range of temperatures as the host. As mentioned earlier the pathogen is active only near the seasonal maximum temperature, and Scheibling and Stephenson (1984) have hypothesized that its appearance is related to unusually warm years.

The potential impact of controlling sea urchins is considerable, especially in areas where the green sea urchin still dominates large areas of the subtidal, e. g. eastern Nova Scotia (own obs.), Newfoundland (Himmelman, 1980; Hooper, 1980), the St. Lawrence River estuary (HimmeIman et al., 1983), Maine, USA (pers. comm., R. L. Vadas, University of Maine), and northern Norway (Hagan, 1983). With the above properties plus its virulence, our ability to maintain it in the laboratory, and our ability to transfer it from the laboratory to the field, the sea urchin disease has considerable potential for use as a biological control agent.

The experimental procedure could be changed by introducing the diseased sea urchins to the field earlier in the summer and in large cages. If the disease were introduced earlier in the summer it could pass through more generations and spread over a larger area before being stopped by falling temperatures. The cages would protect sea urchins weakened by transport or disease from attack by large predators, and the first conspecifics found outside the cages would indicate the first stages of disease transfer to the natural population. However, cages were not used in this study to avoid the risk of losing the entire experiment to curious fishermen or to a severe storm.

Acknowledgements. Drs. J. H. Himmelman of Laval University and R.J. Thompson of Memorial University provided constructive criticism of the manuscript. Miss Darlene Meade and $\mathrm{Mr}$ David Moore assisted in data collection. Dr. R. J. Misra introduced the author to the logit transformation.

\section{LITERATURE CITED}

Bak, R. P. M., Carpay, M. J. E., de Ruyter van Steveninck, E. D. (1984). Densities of the sea urchin Diadema antillarum before and after mass mortalities on the coral reefs of Curaçao. Mar. Ecol. Prog. Ser. 17: 105-108

Boudouresque, C. F., Nedelec, H., Shepherd, S. A. (1981). The decline of a population of the sea urchin Paracentrotus lividus in the Bay of Port-Cros (Var, France). Rapp. Comm. Int. Mer Medit. 27: 223-224

Breen, P. A., Mann, K. H. (1976). Destructive grazing of kelp by sea urchins in eastern Canada. J. Fish. Res. Bd Can. 33: $1278-1283$

Chapman, A. R. O. (1981). Stability of a sea urchin dominated barren ground following destructive grazing of kelp in St. Margarets Bay, eastern Canada. Mar. Biol. 62: 307-311

Debach, P. (1974). Biological control by natural enemies. Cambridge University Press, London

Hagan, N. T. (1983). Destructive grazing of kelp beds by sea urchins in Vestfjorden, northern Norway. Sarsia 68: $177-190$ 
Hirnmelman, J. H. (1980). The role of the green sea urchin, Strongylocentrotus droebachiensis, in the rocky subtidal region of Newfoundland. Can. Tech. Rep. Fish. aquat. Sci. 954: 92-119

Himmelman, J. H., Lavergne, Y., Axelsen, F., Cardinal, A., Bourget, E. (1983). Sea urchins in the Saint Lawrence estuary: their abundance, size-structure, and suitability for commercial exploitation. Can. J. Fish. aquat. Sci. 40: $474-486$

Himmelman, J. H., Steele, D. H. (1971). Foods and predators of the green sea urchin (Strongylocentrotus droebachiensis) in Newfoundland waters. Mar. Biol. 9: 315-322

Hooper, R. (1980). Observations on algal-grazer interactions in Newfoundland and Labrador. Can. Tech. Rep. Fish. aquat. Sci. 954: 120-124

Johnson, P. T. (1971). Studies on diseased urchins from Pt. Loma. In: North, W. J. (ed.) Kelp habitat improvement project, annual report 1970-71. California Institute of Technology, Pasadena, p. 83-90

Lawrence, J. M. (1975). On the relationship between marine plants and sea urchins (Echinodermata: Echinoidea). Oceanogr. Mar. Biol. A. Rev.: 213-286

Leaman, B. M. (1980). The ecology of fishes in British Columbia kelp beds. I. Barkley Sound Nereocystis beds. Fish. Dev. Rep. 22, Minister of the Environment, Province of British Columbia, Victoria, B. C., Canada

Lessios, H. A., Glynn, P. W. and Robertson, D. R. (1983). Mass mortalities of coral reef organisms. Science, N. Y. 222: 715

Mann, K. H. (1972). Ecological energetics of the seaweed zone in a marine bay on the Atlantic coast of Canada. I. Zonation and biomass of seaweeds. Mar. Biol. 12: 1-10

Miller, R. J. (1984). Succession in sea urchin and seaweed abundance in Nova Scotia, Canada. Mar. Biol. (in press)

Miller, R. J., Colodey, A. G. (1983). Widespread mass mortalities of the green sea urchin in Nova Scotia, Canada. Mar. Biol. 73: 263-267

Moreno, C. A., Jara, H. F. (1984). Ecological studies on fish fauna associated with Macrocystis pyrifera belts in the south of Fueguian Islands, Chile, Mar. Ecol. Prog. Ser. 15: 99-107
North, W. J. (1974). A review of studies supporting sea urchin control as a means of restoring kelp beds. In: North, W. J. (ed.) Kelp habitat improvement project, Annual Report 1973-1974. California Institute of Technology Pasadena, p. $95-108$

Pearse, J. S., Costa, D. P., Yellin, M. B., Agegian, C. R. (1977). Localized mass mortality of red sea urchin, Stronglocentrotus franciscanus, near Santa Cruz, California. Fish. Bull. U. S. 75: 645-648

Pearse, J. S., Hines, A. H. (1979). Expansion of a central California kelp forest following the mass mortality of sea urchins. Mar. Biol. 51: 83-91

Pringle, J. D., Sharp, G. J., Caddy, J. F. (1982). Interactions in kelp bed ecosystems in the northwest Atlantic: review of a workshop. In: Mercer, M. C. (ed.) Multispecies approaches to fisheries management advice. Can. Spec. Publ. Fish. aquat. Sci. 59: 108-115

Quast, J. C. (1968). Effects of kelp harvesting on the fishes of kelp beds. Calif. Dept. Fish. Game Fish. Bull. 139: 142-149

Scheibling, R. E. (1984). Echinoids, epizootics and ecological stability in the rocky subtidal off Nova Scotia, Canada Helgoländer Meeresunters. (in press)

Scheibling, R. E., Stephenson, R. S. (1984). Disease related mortality of Strongylocentrotus droebachiensis (Echinodermata: Echinoidea) off Nova Scotia, Canada. Mar. Biol. 73: 153-164

Snedecor, G. W., Cochran, W. G. (1967). Statistical methods Iowa State University Press, Ames, Iowa

Simenstad, C. A., Isakson, J. A., Nakatani, R. A. (1977). Marine fish communities of Amchitka Island, Alaska. In: Merritt, M. L., Fuller, R.G. (ed.) The evironment of Amchitka Island. TID-26712, Nat. Tech. Infor. Serv., U. S. Dept. Commerce, Springfield, Virginia, p. 451-492

Wharton, W. G., Mann, K. H. (1981). Relationship between destructive grazing by the sea urchin, Strongylocentrotus droebachiensis, and the abundance of American lobster, Homarus americanus, on the Atlantic coast of Nova Scotia. Can. J. Fish. aquat. Sci. 38: 1339-1349 